\title{
Comparison of BCYE and BMPA media on recovery rate of Legionella pneumophila
}

DOI: dx.doi.org/10.22435/hsji.v11i1.3127

Lucky H. Moehario ${ }^{1}$, Enty Tjoa ${ }^{1}$, Mutiara J. Taslim², and Yohanna Angelina ${ }^{1}$

${ }^{1}$ Department of Microbiology, School of Medicine and Health Sciences, Atma Jaya Catholic University of Indonesia

${ }^{2}$ Undergraduate Program, School of Medicine and Health Sciences, Atma Jaya Catholic University of Indonesia

Corresponding author: Lucky H Moehario

Email:1hmoehario@gmail.com, lucky.hartati@atmajaya.ac.id

Received: December 18, 2019; Revised: April 23, 2020; Accepted: May 29, 2020.

\begin{abstract}
Abstrak
Latar belakang: Legionella pneumophila (L. pneumophila) telah banyak diketahui sebagai penyebab legionellosis; habitat nya di berbagai sumber air, lingkungan lembab dan hangat. Metode kultur menggunakan media spesifik masih menjadi baku emas untuk identifikasi L. pneumophila. Penelitian ini bertujuan membandingkan recovery rate L. pneumophila ATCC ${ }^{\circledR} 33823$ pada medium spesifik BCYE, dan medium selektif BMPA.
\end{abstract}

Metode: Dilakukan dilusi serial pada suspensi 0,5 McFarland L. pneumophila ATCC ${ }^{\circledR} 33823$; 100 ul dari tiap tingkat dilusi diinokulasi pada medium Buffered Charcoal Yeast Extract (BCYE) dan medium BMPA (medium $B C Y E$ yang ditambahkan suplemen BMPA- $\alpha$ ), secara duplo. Konsentrasi suspensi dihitung menggunakan metode Angka Lempeng Total (ALT) dari Standar Nasional Indonesia No. 01-2332.3-2006. Persentase recovery rate dihitung dan dianalisis secara statistik menggunakan SPSS versi 23,0.

Hasil: Jumlah koloni L. pneumophila yang tumbuh pada medium BMPA jauh lebih tinggi daripada yang tumbuh di medium BCYE; konsentrasi tertinggi yang diperoleh adalah pada medium BMPA sebesar 1,45 $\times 10^{7}$ CFU $/ \mathrm{ml}$. Persentase recovery rate pada medium BMPA adalah 96,67\%, dan 60,67\% pada medium BCYE.

Kesimpulan: Recovery rate medium BMPA untuk pertumbuhan koloni L. pneumophila ATCC ${ }^{\circledR} 33823$ jauh lebih tinggi daripada media BCYE, karena itu medium BMPA dapat direkomendasikan untuk kultivasi L. pneumophila, khususnya pada program surveilans berbagai sumber air dengan biaya lebih terjangkau. (Health Science Journal of Indonesia 2020;11(1):32-7)

Kata kunci: Legionella pneumophila, medium spesifik, BCYE , BMPA, recovery rate

\begin{abstract}
Background: Legionella pneumophila (L. pneumophila) has been known as the etiology of legionellosis; they live in aquatic environment, warm and moist. Culture method using specific medium remains as the gold standard in the identification of $L$. pneumophila. This study aimed to compare the recovery rate of $L$. pneumophila $\mathrm{ATCC}^{\circledR} 33823$ on the specific medium BCYE for the cultivation of Legionella, and BMPA, the selective medium.

Methods: Suspension of L. pneumophila ATCC® 33823 of 0.5 McFarland was diluted to 10 fold serial dilution; 100 ul of each dilution was inoculated on Buffered Charcoal Yeast Extract (BCYE) medium, and BMPA (BCYE supplemented with BMPA- $\alpha$ ) in duplicate manner. The concentration was calculated using Total Plate Count standard as of Indonesian Nasional Standard number 01-2332.3-2006. The percentage of recovery rate was calculated, and the statistical analysis was performed using SPSS version 23.0.
\end{abstract}

Results: Numbers of colonies of L. pneumophila grew on BMPA was much higher than on BCYE medium; the highest concentration was yielded on BMPA medium i.e. $1.45 \times 10^{7} \mathrm{CFU} / \mathrm{ml}$. The recovery rates were $96.67 \%$ and $60.67 \%$ on BMPA medium and BCYE subsequently.

Conclusion: The recovery rate of the BMPA medium on the colony growth of L. pneumophila ATCC $^{\circledR} 33823$ was markedly higher than the BCYE, therefore BMPA medium can be suggested to be used in the cultivation of $L$. pneumophila especially in the routine surveillance program for water sources with less cost. (Health Science Journal of Indonesia 2020;11(1):32-7)

Keywords: Legionella pneumophila, specific medium, BCYE, BMPA, recovery rate 
Legionella pneumophila (L. pneumophila) causes legionellosis with pneumonia as one of the most common clinical manifestations. ${ }^{1,2}$ The incidence of legionellosis in the United State has increased around 4.5 times since 2000, meanwhile cases requiring hospitalisation exceeded average frequency., ${ }^{3}$ L. pneumophila are widespread in freshwaters such as lakes, rivers, and groundwater. These bacteria gain entry to the manmade water reservoir ${ }^{5,6}$ and were detected by Bryne et. al in Pittsburgh (70\%) and Paris $(60 \%)^{6}$ and Al-Matawah Q et. al (2015) in Kuwait which was dominated by $L$. pneumophila serogroup 7.7 In Indonesia, L. pneumophila was found in the swimming pool sample in Surabaya and cooling water samples in Jakarta. ${ }^{8,9}$ Cases of legionellosis in Indonesia were reported in Bali, Karawaci Tangerang and other cities; a survey conducted in 2001 showed that the cases were related to transmission of bacteria from cooling towers. ${ }^{10}$ Regarding these reports, it assumes that Legionella commonly colonize man-made water system, leading to transmission of disease via aerosol. ${ }^{11-13}$ However, legionellosis cases are still underreported, therefore surveillance of $L$. pneumophila is necessary for a long-term approach in eradicating infection. Ministry of Health Republic of Indonesia (2019) has released a regulation no.7/2019 on routine surveillance that should be performed in the water system, especially in cooling towers. $^{14,15}$

The cultivation method remains as the gold standard in L. pneumophila detection. ${ }^{16,17}$ Since the concentration of this bacteria in the building water system was very low and could not be detected by routine sampling, ${ }^{18}$, ${ }^{19}$ Charcoal Yeast Extract (CYE) agar supplemented with Buffered Charcoal Yeast Extract (BCYE), a supplement containing L-cysteine, is used as specific medium. ${ }^{20,21}$ Addition of selective supplements consist of antimicrobials could promote $L$. pneumophila growth and reduce the competing bacteria and fungi. ${ }^{22-24}$ Since the use of lots of media for identification of Legionella is not cost effective, we aimed to evaluate the recovery rate of L. pneumophila $\mathrm{ATCC}^{\circledR} 33823$ on CYE supplemented with BCYE and BCYE-BMPA supplements.

\section{METHODS}

This study was descriptive-analytic research, conducted in the Microbiology Laboratory of Department Microbiology School of Medicine and Health Sciences, Atma Jaya Catholic University Indonesia, from August 2019 to September 2019; this had passed the ethical evaluation by the School of Medicine and Health Sciences, Atma Jaya Catholic University of Indonesia No. 10/08/KEP-FKUAJ/2019.

\section{Bacterial Suspension}

Culti-Loops ${ }^{\mathrm{TM}}$ L. pneumophila ATCC 33823 (Thermo Scientific $^{\mathrm{TM}}$ ) was streak directly according to manual instruction on CYE agar supplemented with BCYE supplement, followed by incubation at $37^{\circ} \mathrm{C}$ in the presence of $5 \% \mathrm{CO}_{2}$ for 3 to 7 days. Observation of the growth of colonies was conducted after 72 hours incubation and regularly every 48 hours to find the growth of expected colonies. Colonies with Legionella morphology characteristics were harvested in $5.0 \mathrm{ml}$ of sterile Phosphate Buffered Saline (PBS) and adjusted to $0.5 \mathrm{McF}$ arland turbidity standard.

\section{Cultivation and Enumeration}

Dilution of $10^{-1}$ was made by transferring $1 \mathrm{ml}$ of $0.5 \mathrm{McF}$ bacterial suspension to $9 \mathrm{ml}$ of diluent (PBS) in the first tube (Tube I) and homogenised by vortex. Every dilution was prepared from drawing $1 \mathrm{ml}$ aliquot from previous dilution. The method was performed in the same manner pas above until $10^{-8}$ dilution. A total of eight tubes represented for dilution of $10^{-1}-10^{-8}$ was obtained, assigned as tube I-VIII. Every suspension must be mixed well using vortex prior to drawing an aliquot for each subsequent serial dilution. The concentration of viable bacteria from each tube was subjected to enumeration by Total Plate Count (TPC) standard from Indonesian Nasional Standard (SNI) number 01-2332.3-2006. ${ }^{25}$

Inoculation was carried out on media as followed: Legionella CYE agar base medium (CM0655 Oxoid $^{\mathrm{TM}}$ ) was added with Legionella BCYE Growth Supplement (SR0110 Oxoid $^{\mathrm{TM}}$ ), referred as BCYE medium, and BCYE medium plus Legionella BMPA- $\alpha$ selective supplement (SR0111 Oxoid ${ }^{\mathrm{TM}}$ ) consists of Cefamandole, Polymyxin B, and Anisomycin, referred as BMPA medium. Both media were tested for fertility by inoculating Culti-Loops ${ }^{\mathrm{TM}}$ Staphylococcus epidermidis ATCC $^{\circledR} 12228$ as recommended by the manufacturer. The expected result was absence of the growth of Staphylococcus epidermidis on BMPA medium, while the growth was observed on BCYE medium. A total of $100 \mathrm{ul}$ aliquots from each dilution was plated onto each media in duplicate manner by spread plate techniques. The inoculated culture media were incubated and inspected in the same condition as above. Viable colonies were counted using colony counter and the concentration (CFU/ml) of sample tested was calculated.

\section{Identification of morphology characteristics and agglutination test}

Characteristics of Legionella colonies identified as greyish-white shiny colonies with the typical ground 
glass appearance, Gram-negative rods, oxidasepositive, catalase-positive. Latex agglutination test was performed for L. pneumohila serogroup identification; Microgen ${ }^{\circledR}$ Legionella Agglutination Kits M45CE was used. The agglutination is expected to occur for the L. pneumohila $\mathrm{ATCC}^{\circledR} 33823$ using reagent test 2-15. This strain of L. pneumopila is identified by the manufacturer as serogroup 7 .

\section{Concentration and recovery rate measurement}

The concentration was measured using the TPC formula, based on Indonesian SNI No. 01-2332.32006, shown below:

$N=\frac{\boldsymbol{\Sigma} C}{\left[\left(1 \times n_{1}\right)+\left(0,1 \times n_{2}\right)\right] x(d)}$

$\mathrm{N}$ : Number of product colonies, expressed in colonies per $\mathrm{ml}$ or colonies per $\mathrm{g}$

$\Sigma \mathrm{C}$ : Number of colonies in all plates counted $\mathrm{n}_{1}$ : Number of plates in the first dilution calculated $\mathrm{n}_{2}$ : Number of plates in the second dilution calculated $\mathrm{d}$ : First dilution calculated

The calculation then multiplied by 10 due to the volume used was $0.1 \mathrm{ml}$.

\section{Recovery rate}

\section{$\frac{N 1}{N 0} \times 100 \%$}

$\mathrm{N} 1$ : Number of colony forming units per ml (CFU/ $\mathrm{ml}$ ) obtained

N0 : Number of colony forming units per ml (CFU/ $\mathrm{ml})$ as equal to $0.5 \mathrm{McF}$ arlands $\left(1.5 \times 10^{7} \mathrm{CFU} / \mathrm{ml}\right)$

The percentage of recovery rate was calculated by dividing the concentration obtained by the initial concentration and multiplied by $100 .^{26,27}$

\section{Statistical analysis}

Statistical analysis was carried out using a t-independent test to compare the concentration $(\mathrm{CFU} / \mathrm{ml})$ on BCYE and BMPA media using SPSS software version 23.0, 2015 with $P<0.05$ was significance, and 95\% confidence interval. Normality of the data was tested using Shapiro Wilk test. If the value is greater than 0.05 , it shows a normal distribution. Mann Whitney $U$ test was used instead if the distribution was not normal.

\section{RESULTS}

The identification of the colonies was conducted on day 5 of incubation since at this time of incubation colony morphology has shown its best. The bacteria colonies were identified by morphologies characteristics, Gram staining, biochemical and agglutination test as mention in the method above. The results on all plates by a $100 \mathrm{ul}$ diluted bacterial suspension from tube I to tube VIII showed colonies with characteristics of L. pneumophila; agglutination occurred when tested with Microgen ${ }^{\circledR}$ Legionella Agglutination Kits M45CE, which confirmed of the presence of $L$. pneumophila serogroup 2-15. The growth of expected colonies of L. pneumophila was observed on BCYE plates inoculated by the bacterial suspension from tube I to tube $\mathrm{V}$, while on BMPA plates, colonies growth was observed up to tube VI, which was 10 fold more diluted than tube V. Numbers of colonies on each plate were counted, and the concentration of the bacterial suspension in each tube was calculated using the TPC formula (Indonesian SNI No. 01-2332.3-2006). The results were as shown in Table 1 and 2.

Table 1. Colonies number of L. pneumophila ATCC 33823 and the concentration yielded from the cultivation on BCYE medium

\begin{tabular}{cccccc}
\hline \multirow{2}{*}{ Tube } & Dilution & \multicolumn{3}{c}{ Colonies number } & Concentration \\
\cline { 3 - 5 } & & I & II & Mean & TNTC* TNTC* $^{*}$ \\
I & $10^{-1}$ & TNTC* & TNTC* & TNTC* TNTC* $^{*}$ & $0.54 \times 10^{7}$ \\
II & $10^{-2}$ & TNTC* & TNTC* & 540 & $0.91 \times 10^{7}$ \\
III & $10^{-3}$ & 510 & 570 & 90.5 & $0.50 \times 10^{7}$ \\
IV & $10^{-4}$ & 95 & 86 & 5 & 0 \\
V & $10^{-5}$ & 2 & 8 & 0 & 0 \\
VI & $10^{-6}$ & 0 & 0 & 0 & 0 \\
VII & $10^{-7}$ & 0 & 0 & 0 & 0 \\
VIII & $10^{-8}$ & 0 & 0 & & \\
\hline
\end{tabular}

*Too Numerous Too Count 
The highest concentration obtained on BCYE and BMPA media was of those that were inoculated by bacterial suspension of tube IV which gave a concentration of $0.91 \times 10^{7} \mathrm{CFU} / \mathrm{ml}$ and $1.45 \times 10^{7}$ $\mathrm{CFU} / \mathrm{ml}$ respectively. Further, on the BMPA plates, colonies growth was observed up to tube VI, and resulted to a concentration of $1.00 \times 10^{7} \mathrm{CFU} / \mathrm{ml}$, while it only showed colonies up to dilution $10^{-5}$ (tube $\mathrm{V}$ ), which produced a concentration $0.50 \times 10^{7}$ $\mathrm{CFU} / \mathrm{ml}$ on BCYE medium.

Table 2. Colonies number of L. pneumophila ATCC 33823 and the concentration yielded from the cultivation on BMPA medium

\begin{tabular}{|c|c|c|c|c|c|}
\hline \multirow{2}{*}{ Tube } & \multirow{2}{*}{ Dilution } & \multicolumn{3}{|c|}{ Colonies number } & \multirow{2}{*}{$\begin{array}{c}\text { Concentration } \\
(\mathrm{CFU} / \mathrm{ml})\end{array}$} \\
\hline & & $\mathrm{I}$ & II & Mean & \\
\hline I & $10-^{1}$ & TNTC* & TNTC* & TNTC* & TNTC* \\
\hline II & $10-^{2}$ & TNTC* & TNTC* & TNTC* & TNTC* \\
\hline III & $10-^{3}$ & 840 & 990 & 915 & $0.92 \times 10^{7}$ \\
\hline IV & $10-^{4}$ & 150 & 140 & 145 & $1.45 \times 10^{7}$ \\
\hline V & $10-^{5}$ & 5 & 14 & 9.5 & $0.95 \times 10^{7}$ \\
\hline VI & $10-^{6}$ & 1 & 1 & 1 & $1.00 \times 10^{7}$ \\
\hline VII & $10-^{7}$ & 0 & 0 & 0 & 0 \\
\hline VIII & $10-^{8}$ & 0 & 0 & 0 & 0 \\
\hline
\end{tabular}

*Too Numerous Too Count

The recovery rate of BCYE and BMPA medium was calculated by dividing the concentration obtained, i.e. from tube IV of the BCYE and BMPA by the initial concentration of the bacterial suspension used, i.e. $0.5 \mathrm{McF}$ arland $\left(1.5 \times 10^{7} \mathrm{CFU} / \mathrm{ml}\right)$ and multiplied by 100 ; thus showed $60.67 \%$ and $96.67 \%$ respectively, where the BMPA medium had a much higher recovery rate than $\mathrm{BCYE}$ medium. Colonies grew from tube IV were chosen referring to SNI number 01-2332.3.-2006 in which showed colonies range from 25-250 colonies. The distribution of data obtained using Shapiro Wilk test showed normal distribution. Comparison of the concentration from each medium was carried out from tube III-V as shown in Figure 1, and was statistically analysed using t-independent test, the result showed $\mathrm{p}$-value of $0.102(P>0.05)$. Both medium showed similar growth capability for L. pneumophila, nevertheless, the BMPA medium had much higher recovery rate than the BCYE.

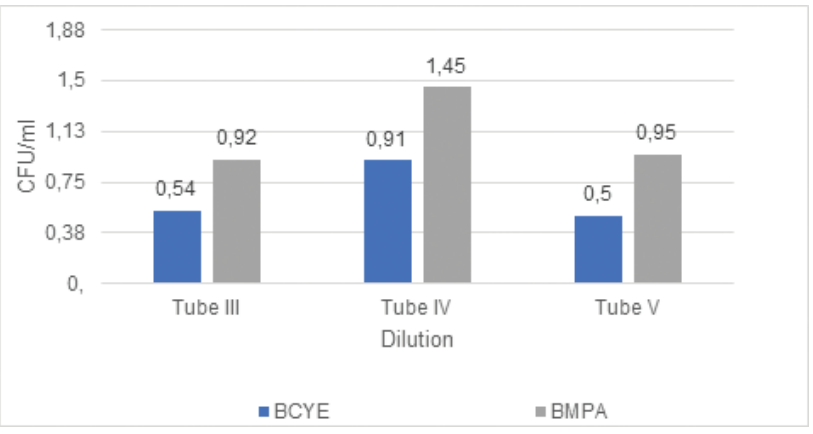

Figure 1. The concentration (CFU/ml) of tube III, IV, and $V$ plated on BCYE and BMPA media
This figure showed the concentration (CFU/ml) obtained from three different dilutions of bacterial suspension inoculated on BCYE and BMPA agar. The $\mathrm{CFU} / \mathrm{ml}$ showed up from the cultivation on BMPA agar was higher than on BCYE. Moreover, the highest concentration was obtained from the suspension dilution of $10^{-4}$ cultivated on BMPA medium.

\section{DISCUSSION}

The present study used different medium formulations for the recovery of $L$. pneumophila strain. We compared the recovery rate and concentration on BCYE and BMPA medium and showed the BMPA medium had better performance than BCYE. A study by Descours et. al (2014) showed selective media supplemented with antibiotic and anti fungi yielded higher isolation rates than $\mathrm{BCYE}$ medium. ${ }^{28}$ On the contrary, however, statistical analysis demonstrated no significant difference in L. pneumophila growth on BCYE and BMPA media $(P=0.102$, t-independent test $)$.

The ability of a medium for the isolation of $L$. pneumophila varies depend on the sample types and medium composition. Edelstein (1981) isolated $L$. pneumophila from the contaminated water specimen and showed a significant difference of mean viable counts on BCYE and BMPA media. ${ }^{29}$ BCYE medium is specific but not selective for the isolation of $L$. pneumophila due to absence of antibiotics component to inhibit contaminants. Our study, however, we used sterile Phosphate Buffered Saline (PBS) that has 
been seeded with L. pneumophila, of which none of the contaminants were present. Thus, it could be assumed that there would be no significant difference in growth on BCYE and BMPA media using PBS seeded with L. pneumophila.

Pharmacopeia recommends a recovery rate of 50\%$200 \%$, whereas the recovery rate of L.pneumophila on BCYE (60.67\%) and BMPA(96.67\%) media were within the range. ${ }^{30}$ Recovery rates could vary depending on the type of water sample. ${ }^{31}$ Boulanger and Edelstein stated that the results obtained could be different between seeded water samples and actual water specimens, further the presence of other flora in water specimens could decrease the recovery of L. pneumophila. ${ }^{27}$ Fliermans et al. $(1981)^{31}$ found the recovery rate of Legionella from seeded water samples was consistently around $80 \%$, whereas the BMPA medium in the present study showed higher i.e. $96.67 \%$. Our earlier study of water resources from tap water, water reservoir, condensed water from split air conditioning (AC), and hot water obtained from two private hospitals in Jakarta showed a better growth of L. pneumophila on BMPA. ${ }^{32}$ Edelstein $(1981)^{29}$ recommended a laboratory with limited funds could use BMPA medium which might show lower yield instead of using BCYE medium with a higher risk of contamination. The present study is in agreement with Edelstein that the use of BMPA medium increases both selectivity and sensitivity of L. pneumophila.

In conclusion, the present study demonstrated the recovery rate of $L$. pneumophila was markedly higher on the BMPA medium than BCYE. Therefore, the BMPA medium can be suggested to be used for cultivation of L. pneumophila, especially in the routine water sources surveillance program with less cost.

\section{Conflict of interest}

The authors declare that there are no conflicts of interest regarding the publication of this paper.

\section{REFERENCES}

1. CDC [Internet]. About legionnaires disease and pontiac fever. 2019. [Cited 2020 May 25]. Available from: https://www.cdc.gov/legionella/about/index.html.

2. Farver CF. Bacterial Diseases. Pulmonary Pathology [Internet]. 2nd ed. Philadelphia, PA: Elsevier; 2018. [Cited 2018 Sep 16] p 163-200. Available from: https:// www.clinicalkey.com/\#!/content/book/3-s2.0 B978032 3393089000108 ? scrollTo $=\% 23 \mathrm{hl} 0001580$.
3. Yackley JK. $<\mathrm{em}>$ Notes from the Field $</ \mathrm{em}>$ : Legionellosis outbreak associated with a hotel aquatics facility - Tennessee, 2017. [Cited 2019 Dec 6]. MMWR Morb Mortal Wkly Rep [Internet]. 2018; 67. Available from: https://www.cdc.gov/mmwr/volumes/67/wr/ mm6702a5.html .

4. Edelstein PH. Legionnaires' disease, pontiac fever, and related illnesses. In: Feigin and Cherry's Textbook of Pediatric Infectious Diseases [Internet]. 8th ed. Philadelphia, PA: Elsevier; 2019. [Cited 2018 Sep 18] p 1228-1235. e4. Available from: https://www.clinicalkey. com/\#!/content/book/3-s2.0-B9780323376921001374? scrollTo $=\% 23 \mathrm{hl} 0000638$.

5. Rubin LG. Legionella Species. Principles and Practice of Pediatric Infectious Diseases [Internet]. 5th ed. Philadelphia, PA: Elsevier; 2018 [Cited 2018 Sep 16]; p. 948-952.e1. Available from: https://www.clinicalkey. com/\#!/content/book/3-s2.0-B9780323401814001778? scrollTo $=\% 23 \mathrm{hl} 0000336$.

6. Byrne BG, McColm S, McElmurry SP, Kilgore PE, Sobeck J, Sadler R, et al. Prevalence of infectioncompetent serogroup 6 Legionella pneumophila within premise plumbing in Southeast Michigan. mBio. 2018 Mar 7; 9(1): e00016-18.

7. Al-Matawah Q, Al-Zenki S, Al-Azmi A, Al-Waalan $\mathrm{T}$, Al-Salameen F, Hejji AB. Legionella detection and subgrouping in water air-conditioning cooling tower systems in Kuwait. Environ Sci Pollut Res Int. 2015 Jul; 22(13): 10235-41.

8. Aksono EB, Farahdiba AA, Hestianah EP. Legionella pneumophila bacteria detected in swimming pool water of Surabaya by using nested Polymerase Chain Reaction. J Vet. 2017; 18(2): 221-5.

9. Yasmon A, Yusmaniar Y, Anis A, Bela B. Simultaneous detection of Legionella species and Legionella pneumophila by duplex PCR (dPCR) assay in cooling tower water samples from Jakarta, Indonesia. Med J Indones. 2010 Nov 1; 19(4): 223-7.

10. Ministry of Health Republic of Indonesia. Minister of Health Decree No. 1538/Menkes/SK/1/2003 about Standards of Legionella Specimen Management. Jakarta : Ministry of Health of Indonesia. 2003.

11. Sikora A, Wojtowicz-Bobin M, Koziol-Montewka M, Magrys A, Gladysz I. Prevalence of Legionella pneumophila in water distribution systems in hospitals and public buildings of the Lublin region of eastern Poland [Internet]. [Cited 2020 May 25]. Available from: http://www.aaem.pl/Prevalenceof-Legionella-pneumophila-in-water-distributionsystems-in-hospitals and,72258,0,2.html/doi. org/10.5604/12321966.1152064.

12. D'Alessandro D, Fabiani M, Cerquetani F, Orsi G. Trend of legionella colonization in hospital water supply. Ann Ig Med Prev E Comunità. 2015 Jun 5; 27: 460-6.

13. Prussin AJ, Schwake DO, Marr LC. Ten questions concerning the aerosolization and transmission of Legionella in the built environment [Internet]. [Cited 
2020 May 25]. Available from: https://www.ncbi.nlm. nih.gov/pmc/articles/PMC5665586/

14. Ministry of Health Republic of Indonesia. Minister of Health Decree No 7 Th 2019 ttg Kesehatan Lingkungan_Rumah_Sakit.pdf [Internet]. [Cited 2019 Oct 29]. Available from: http://aspak.yankes.kemkes. go.id/beranda/wpcontent/uploads/downloads/2019/03/ PMK_No_7 Th_2019_ttg_Kesehatan_Lingkungan Rumah_Sakit.pdf.

15. Agarwal S, Abell V, File TM. Nosocomial (Health Care-Associated) legionnaire's disease. Infect Dis Clin North Am. 2017 Mar; 31(1): 155-65.

16. Mercante JW, Winchell JM. Current and emerging Legionella diagnostics for laboratory and outbreak investigations. Clin Microbiol Rev. 2015 Jan; 28(1): 95-133.

17. Kotrbancová M, Špaleková M, Fulová M, Trnková K, Perželová J. Legionellosis and its diagnosis. Epidemiol Mikrobiol Imunol Cas Spolecnosti Epidemiol Mikrobiol Ceske Lek Spolecnosti JE Purkyne [Internet]. 2017; 66(3): 133-9. [Cited 2020 May 25]. Available from: https://pubmed.ncbi.nlm.nih.gov/28948808/

18. Giglio O, Diella G, Trerotoli P, Consonni M, Palermo R, Tesauro M, et al. Legionella detection in water networks as per ISO 11731:2017: can different filter pore sizes and direct placement on culture media influence laboratory results? Int J Environ Res Public Health. 2020 Mar 20; 17: $1-8$.

19. CDC [Internet]. Monitoring your building water for Legionella. 2019. [Cited 2020 May 25]. Available from: https://www.cdc.gov/legionella/wmp/monitor-water. html.

20. Whelen C. Legionella and Bordetella. Textbook of diagnostic microbiology. 6th ed. Philadelphia: Saunders; 2018. p. 401-7.

21. Caroll KC, Brooks GF, Jawetz E, Melnick JL, Adelberg EA (ed). Bacteriology. Jawetz, Melnick, \& Adelberg's medical microbiology. 28th ed. New York: McGraw Hill Medical; 2019. p. 315-8.

22. Pierre DM, Baron J, Yu VL, Stout JE. Diagnostic testing for Legionnaires' disease. Ann of Clin Microbiol and Antimicrob [Internet]. 2017 August 29 [Cited 2020 May 24]; 16 (59) : 1-4. Available from: https://annclinmicrob. biomedcentral.com/articles/10.1186/s12941-017-0229-6

23. Veenendaal HR, Brouwer-Hanzens AJ, van der Kooij D. Incubation of premise plumbing water samples on Buffered Charcoal Yeast Extract at elevated temperature and $\mathrm{pH}$ selects for Legionella pneumophila. Water Res. 2017 15; 123: 439-47.
24. Engl ards unit NISPH, st 61 Colindale Avenue London NW9 5EQ Email, st. UK Standards for Microbiology Investigation: ID 18 Identification of Legionella species - GOV.UK. Public Health Engl. (03): 09-13. Public Health England. (2015).

25. Badan Standardisasi Nasional. Cara uji mikrobiologibagian 3: penentuan angka lempeng total (ALT) pada produk perikanan. Standar Nasional Indonesia. Jakarta; 2006. Indonesian.

26. Roelofsen E, Leeuwen MV, Meijer-Severs GJ, Wilkinson MHF, Degener JE. Evaluation of the effects of storage in two different swab fabrics and under three different transport conditions on recovery of aerobic and anaerobic bacteria. Journal of Clinical Microbiology [Internet]. 1999 [Cited 2019 October 30]; 37(9): 3041-3. Available from: https://jcm.asm.org/content/37/9/3041.

27. Catherine AB, Edelstein PH. Precision and accuracy of recovery of Legionella pneumophila from seeded tap water by filtration and centrifugation. Applied and Environmental Microbioogyl [Internet]. 1995 [Cited 2019 November 21]; 61(5):1805-9. Available from: https://aem.asm.org/content/aem/61/5/1805.full.pdf

28. Descours G, Cassier P, Forey F, Ginevra C, Etienne J, Lina G, et al. Evaluation of BMPA, MWY, GVPC and BCYE media for the isolation of Legionella species from respiratory samples. J Microbiol Methods [Internet]. 2014 Mar 1; 98: 119-21. Available from: 10.1016/j. mimet.2014.01.001.

29. Edelstein PH. Improved semiselective medium for isolation of Legionella pneumophila from contaminated clinical and environmental specimens. J Clin Microbiol [Internet]. 1981 Sep [Cited 2018 August 16];14(3):298303. Available from: https://jcm.asm.org/content/ jcm/14/3/298.full.pdf.

30. Council of Europe. Microbial examination of non-sterile products: microbial enumeration tests. Pharmacopeia. 2018.

31. Fliermans CB, Cherry WB, Orrison H, Smith SJ, Tison DL, Pope DH. Ecological niche of Legionella pneumophila. Applied and Environmental Microbiology. 1981;41(1):9-16.

32. Moehario LH, Robertus T, Grace Y, Tjoa E. Screening of Legionella pneumophila from water sources in the hospitals in Jakarta. Health Science Journal of Indonesia [Internet]. 2019 [Cited 2018 August 15]; 10(1):21-6. Available from: https:/www.ncbi.nlm.nih.gov/pmc/ articles/PMC243633/pdf/aem00194-0029.pdf. 